\title{
在宅高齡者のための日常生活動作能力調査票の作成
}

\author{
出 村 慎一1）佐 藤 進 ${ }^{2)}$ 南 雅 樹 ${ }^{3)}$ 小林 秀 紹 ${ }^{4)}$ \\ 野 田 洋 平 ${ }^{5 ）}$ 松 沢 甚三郎 ${ }^{6)}$ 小 林 寛 道 ${ }^{7)}$ 青 木 純一郎 ${ }^{8)}$
}

\section{DEVELOPMENT OF ADL INDEX FOR OLDER COMMUNITY PEOPLE}

\author{
Shinichi Demura, Susumu Sato, Masaki Minami, Hidetsugu Kobayashi, \\ Yohei Noda, Jinzaburo Matsuzawa, Kando Kobayashi and Jyunichiro AoKi
}

\begin{abstract}
The purposes of this study were to examine reliability and validity of ADL index for older people at home, and relationships between ADL score and various factors (ex. self-assessment of health status and physical fitness level, and exercise frequency/week), and to examine the screening basis for execution of physical fitness test based on distribution of ADL score. A questionnaire consisting of $12 \mathrm{ADL}$ items and a physical fitness test of Ministry of Education, Science and Clture were administered to 5,715 subjects 65 years or more age (male :2,745; female :2,970). As a result of examining test-retest reliability of the ADL index, significant high correlations were shown among $12 \mathrm{ADL}$ items $(0.674 \leqq \mathrm{r} \leqq 0.886)$, and in overall score $(r=0.943)$. The ADL score was significantly related to age and physical fitness test scores, and tended to be higher in subjects with a higher self-assessment of health status and physical fitness level, and with more frequency. It was suggested that these results prove the utility of the present ADL index. Further, as the result of examining relationships between distribution of overall ADL score and physical fitness test scores, the following screening bases were considered to be valid for judgement whether the physical fitness tests could be executed. The three screening bases using overall ADL score were : 1) 12 or under ; 2) over 13 to under $24 ; 3) 24$ and over. The four bases using item score were : 1) a category 1 response for items 1,5 and $6 ; 2$ ) a category 2 or 3 response for items 1,5 and 6 , and a category 1 response for items 3 and $4 ; 3$ ) a category 3 response for items 2 and $14 ; 4$ ) a category 1 response for items 10 and 12 .
\end{abstract}

(Jpn. J. Phys. Fitness Sports Med. 2000, $49: 375 \sim 384$ )

key word：ADL 調查票, 高齢者, 信頼性, 妥当性, スクリーニング基準

\footnotetext{
1) 金沢大学教育学部 干920-1192 石川県金沢市角間町

2) 金沢工業大学 テ921-8501 石川県野々市町扇が丘7-1

3) 金沢美術工芸大学 テ920-8656 石川県金沢市小立野5-11-1

4) 福井工業高等専門学校 干916-8507 福井県鯖江市下司町

5) 茨城大学教育学部 ○310-0056 茨城県水戸市文京2-1-1

6) 福井医科大学 干910-1194 福井県吉田郡松岡町下合月

7) 東京大学生命環境科学系 广153-8902 東京都目黒区駒場3-8-1

8) 順天堂大学健康科学部 干270-1695 千葉県印旛郡印旛村平賀学園台1-1

Faculty of Education, Kanazawa University. Kakuma, Kanazawa, Ishikawa, 920-1192.

Life-long Sports Core, Kanazawa Institute of Technology. 7-1 Ohgigaoka, Nonoichi, Ishikawa, 921-8501.

Kanazawa College of Art. 5-11-1 Kodatsuno, Kanazawa, Ishikawa, 920-8656.

Fukui National College of Technology. Geshi, Sabae, Fukui, 916-8507

Faculty of Education, Ibaraki University. 2-1-1 Bunkyo, Mito, Ibaraki, 310-0056.

Fukui Medical School. Shimoaitsuki, Matsuoka, Yoshida, Fukui, 910-1194.

Department of Life Science, The University of Tokyo. 3-8-1 Komaba, Meguro, Tokyo, 153-8902

School of Health and Sports Science, Jyuntendo University. 1-1

Hiragagakuendai, Inba-mura, Inba-gun, Chiba, 270-1695
} 
目的

高齢者の身体能力に関しては，第一に自立した 日常生活を営む上で必要とされる身体能力の有 無，第二に，より活発に活動するために必要な身 体能力をどの程度有しているかが重要視される 1 3). 前者は一般に日常生活の中で行われる諸 動作が他人の介助なしに成就可能か否かにより評 価され, 後者は体力テストや運動能力テストなど の最大能力発揮に基づくパフォーマンステストに より評価される．高齢者の身体能力を安全に測 定・評価するには，まず一定水準の日常生活動作 ( $\mathrm{ADL})$ 能力を有していることを確認した上で, 各体力要素を評価しなければならない.したがっ て, 高齢者が日常生活の自立に必要とする動作能 力を評価でき, かつ, 体力テスト実施に関するス クリーニングテストとしても利用可能な ADL 調 查票の有用性は高いと考えられる4).

我々はこれまで, 在宅高龄者を対象とした $\mathrm{ADL}$ 調查票の作成を目的とし, 理論的・実証的 な検討を試みてきた ${ }^{1,5 \sim 8)}$ 。具体的には，理論的 妥当性を考虑して抽出したADL 項目について, 予備調査の結果を踏まえて項目内容および評価尺 度の検討を行い, 有効と考えられる12項目 ( 3 段 階尺度）を選択した ${ }^{6)}$. しかし，これらの項目の 信頼性や実証的妥当性, 動作能力に影響を及ほす と考えられる種々の要因との関連性については十 分に検討していない. 加えて，大きな標本に基づ く得点分布や体力テストの実施に関するスクリー ニング基準について検討するには至っていない.

そこで本研究では, 第一に, これら ADL 12 項 目について, 信頼性, 実証的妥当性 (加齡変化お よび体力実測値との関係)，および外的要因(健康 度・体力自己評価, 運動実施状況) との関係につ いて検討し本調查票の有効性を明らかにするこ と，第二に，得点分布を分析し体力テストの実施 に関するスクリーニング基準を示すことを目的と した.
方

法

\section{1. 標 本}

本研究の被験者は, 健常な65歳以上の在宅高齢 者5715名(男性2745名，女性2970名)であった，被 験者の性別・年齢別内訳および平均年齢は表 1 に 示した.

表 1. 標本内訳および平均年齢

\begin{tabular}{l|cccrcc}
\hline 年䑪 & \multicolumn{3}{c}{ 男性 } & \multicolumn{3}{c}{ 女性 } \\
段隋 & $\mathrm{n}$ & Mean & SD & $n$ & Mean & SD \\
\hline $65 \sim 69$ & 967 & 66.9 & 1.44 & 1151 & 66.8 & 1.43 \\
$70 \sim 74$ & 962 & 71.8 & 1.43 & 1006 & 71.6 & 1.38 \\
$75 \sim$ & 816 & 76.6 & 1.48 & 813 & 76.5 & 1.37 \\
\hline
\end{tabular}

注）平均年龄に関して，有意な年代差のみ認められ た. 80 歳以上は 3 名のみであった.

\section{2. $A D L$ 調查}

本研究における調査票は, 高齢者が健康で自立 した日常生活を営む上で必要な, 健康関連体力を 中心とした生活機能の評価および, 体力テストの 実施に関するスクリーニング・テストとしての利 用を目的としている，本研究では，前報6)におい て有効とされた12項目を用いた。これらの項目は 4動作領域 (移動系動作, 操作系動作, 平衡系動作, 姿勢変換系動作) 10動作群 (1. 移動・階段昇降 · 移乗, 2. 起居. 姿勢保持, 3. 更衣, 4. 食事, 5. 調理, 6. 掃除, 7. 運搬, 8. 入浴, 9 . 排泄・整容, 10 . 生活関連 - その他) から抽出さ れている. また, Caspersen et al. ${ }^{2)}$ が示す健康関 連体力 (Health-related physical fitness) $の$ 構成要 素 (1)筋力, (2)筋持久力, (3)全身持久力, (4)柔軟性) および, (5)平衡性や(6)巧緻性・器用性との関連も 仮定されている6). 各項目は難易度の異なる動作 を用いた 3 つの選択肢からなり, 被験者には現在 の自分の状態に最も近いもの一つを選択させた (表 2).また，100名を対象に再テスト法により $\mathrm{ADL}$ 項目の信頼性を検討した。調查の間隔は約 $2 \sim 3$ 週間であった. 各項目は 3 点満点で評価(難 易度が低いカテゴリから順に 1 点, 2 点, 3 点を 付与)した. 全ての項目に回答した場合の総合得 点の範囲は 12 - 36点であった(何らかの理由によ 
表 2. 調 査 項 目

\begin{tabular}{|c|c|c|c|}
\hline 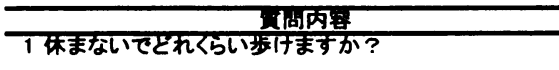 & \multicolumn{3}{|c|}{ 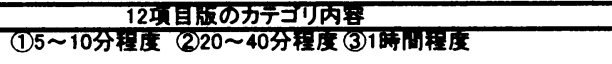 } \\
\hline 2 休まないで゙れくらい走れますか？ & (1)走れない & (2) 3 5分程度 & (3)10分以上 \\
\hline 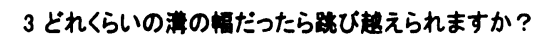 & (1)できない & (2) $30 \mathrm{~cm}$ 程度 & (3) $50 \mathrm{~cm}$ 程度 \\
\hline 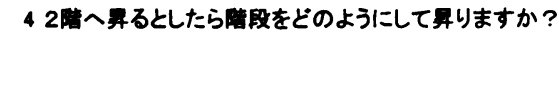 & \multicolumn{3}{|c|}{ 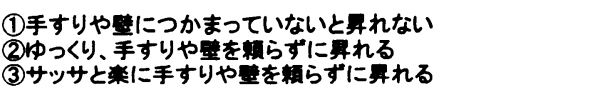 } \\
\hline 5 正座の䋈壆からどのようにして立ち上がれますか？ & \multicolumn{3}{|c|}{$\begin{array}{l}\text { (1)できない } \\
\text { (2)手を杘につけてないと亲ち上がれない } \\
\text { (3)手を使わずに立ち上がれる }\end{array}$} \\
\hline 6 目を開けて片足で何秒くらい立っていられますか？ & (1)できな & \multicolumn{2}{|c|}{ (2)10 20秒程度 (3)30秒以上 } \\
\hline 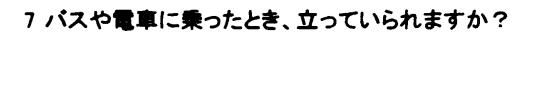 & \multicolumn{3}{|c|}{ 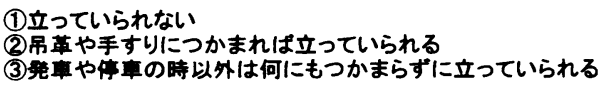 } \\
\hline 8 立ったままでズ゙ンやスカートがはけますか？ & \multicolumn{3}{|c|}{$\begin{array}{l}\text { (1)應らないとできない } \\
\text { (2)何かにつがれは立ってできる } \\
\text { (3)何にもつかまらなで立つたままできる }\end{array}$} \\
\hline 9 シャ゙ツの前ボタンを数けたたり外したりできますか？ & \multicolumn{3}{|c|}{ 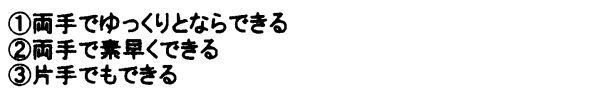 } \\
\hline 10 布団の上げ下ろしができますか？ & \multicolumn{3}{|c|}{ 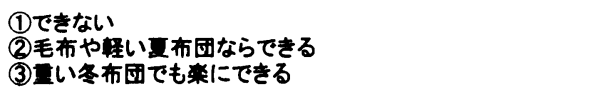 } \\
\hline 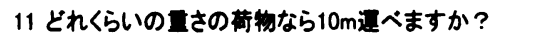 & (1)できない & (2) $5 \mathrm{~kg}$ 程度 & (3) $10 \mathrm{~kg}$ 程度 \\
\hline 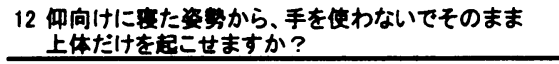 & (1できない & (2)1 2回程度 & (3)3 4回以上 \\
\hline
\end{tabular}

り，回答できない項目がある場合には12点以下に なる).

\section{3. 体カテスト項目および自己評価項目}

文部省新体力テスト(握力, 長座体前屈, 開眼 片足立ち, 上体起こし, $10 \mathrm{~m}$ 歩行, 6 分間歩行） を実施した。体力テストに加え, 健康度・体力自 己評価, および運動実施状況についても調査した。 健康度自己評価は仯おいに健康, まあ健康，あ まり健康でない\}，体力自己評価は 㑑信がある， 普通である, 不安がある\}, 運動実施状況は 任 とんど毎日(週 3〜 4 日以上), ときどき(週 1 2 日程度), ときたま(月 $1 \sim 3$ 日程度) $\}$ の各力 テゴリをそれぞれ用いた。

\section{4. 解析方法}

まず(1)カテゴリ度数，(2)体力テスト項目との関 連, (3)ADL 項目相互の関連, (4)年齢との関係, (5)健康度・体力自己評価および運動実施状況との
関係について検討した，(1)では，度数及び相対度 数を算出した. (2), (3), (4)ではPearsonの相関 係数を算出した。(5)ではカテゴリごとに ADL 得 点の平均値を算出し，分散分析によりカテゴリ間 の差を検討した。 また信頼性は，再テスト法に基 づく回答の一致度について Pearson 相関係数に より検討した．さらに，ADL 総合得点の分布を 検討するために，度数分布および累積相対度数分 布を算出した.

結果

\section{1. カテゴリ別の度数}

各項目のカテゴリ別の度数を表 3 に示した. 最 も難易度の高いカテゴリ (3)の相対度数は $21.8 \%$ (走る) $77.3 \%$ (ズボンをはく)であった。 また， カテゴリ (1)の相対度数が $50 \%$ 以上であった項目は なく，カテゴリ(2)で項目 2 (走る)，6（開眼片足 立ち), 7 (乗り物内立位保持) 33 項目, カテゴ リ (3)で項目 3 (溝を跳び越える)，5 (起立)，8 (ズ 
表 3．ADL 項目のカテゴリ度数, 無回答率, 信頼性

\begin{tabular}{|c|c|c|c|c|c|c|c|c|}
\hline & \multicolumn{2}{|c|}{ カテコリ1 } & \multicolumn{2}{|c|}{ カテป゙リ2 } & \multicolumn{2}{|c|}{ カテゴリ3 } & \multirow[b]{2}{*}{ 每回䈍聂 } & \multirow[b]{2}{*}{ 昷罢性 } \\
\hline & 庭数 & $\%$ & 度数 & $\%$ & 度数 & $\%$ & & \\
\hline 步人 & 436 & 8.1 & 2423 & 44.7 & 2556 & 47.2 & 5.25 & 0.792 \\
\hline 走る & 1191 & 22.1 & 3015 & 56.0 & 1174 & 21.8 & 5.86 & 0.787 \\
\hline 洋を趾び越える & 315 & 5.8 & 1955 & 36.3 & 3122 & 57.9 & 5.65 & 0.886 \\
\hline 䐗段歩行 & 457 & 8.4 & 2399 & 44.2 & 2566 & 47.3 & 5.13 & 0.832 \\
\hline 起立 & 227 & 4.2 & 2031 & 37.5 & 3164 & 58.4 & 5.13 & 0.807 \\
\hline 闌眼只足立ち & 415 & 7.8 & 3004 & 56.2 & 1930 & 36.1 & 6.40 & 0.787 \\
\hline 乗り物内立位保持 & 413 & 7.6 & 2820 & 52.1 & 2181 & 40.3 & 5.27 & 0.741 \\
\hline スボン & 238 & 4.4 & 997 & 18.4 & 4190 & 77.3 & 5.11 & 0.813 \\
\hline シャツツ & 810 & 14.9 & 2431 & 44.8 & 2183 & 40.2 & 5.09 & 0.674 \\
\hline 布団上げ下ろし & 125 & 2.3 & 1336 & 24.7 & 3957 & 73.0 & 5.20 & 0.783 \\
\hline & 22 & 4.1 & 2040 & 37.7 & 3144 & 58.1 & 5.37 & 0.881 \\
\hline $2-1$ & 1412 & 26.2 & 2096 & 38.9 & 1874 & 34.8 & 5.83 & 0.785 \\
\hline
\end{tabular}

注）信頼性(再テスト)は Pearson の相関係数により算出した．総合得点の信 頼性は0.943.

ボン), 10 (布団の上げ下げ), 11 (運搬)の 5 項目 が相対度数 $50 \%$ 以上に該当した. いずれのカテゴ リの相対度数も50\%未満で回答が分散した項目 は, 項目 1 (歩く)，4 (階段昇降)，9 (シャツ), 12 (上体起こし)の 4 項目であった。

\section{2. 信頼性の検討}

再テスト法により各項目の信頼性を検討した結 果を表 3 に示した. 各項目の相関係数は 0.674 (シャツ) 0.886(溝を跳び越える)の比較的高い 值を示した。総合得点では，0.943の高い值が認 められた。

\section{3. 体力実測值，年齡および ADL 項目相互間の 関係}

体力実測値および年齢と ADL 項目相互間の相 関係数を表 4 に示した。体力実測値は, 全ての $\mathrm{ADL}$ 項目と体力テスト項目の間に有意な相関係 数の值が認められた．年齡との関係においても， 全ての ADL 項目が年齢と有意な負の相関を示し た。また，ADL 項目相互間の関係では, 全ての 項目間で有意な值が認められた。

\section{4. 健康度・体力自己評価および運動実施状況と の関係}

健康度自己評価, 体力自己評価, 運動実施頻度 のカテゴリ別に体力実測値および ADL 得点の有 意差を検討した結果を表 5 に示した．全ての

表 4. 体力テスト, ADL 項目の相互間の関係

\begin{tabular}{|c|c|c|c|c|c|c|c|c|c|c|c|c|c|c|c|c|c|c|c|c|}
\hline & 1 & 2 & 3 & 4 & 4 & 5 & 7 & 8 & 9 & 10 & 11 & 12 & 13 & 14 & 15 & 16 & 17 & 18 & 19 & 20 \\
\hline 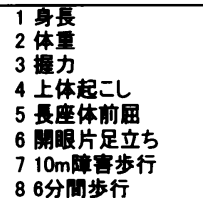 & $\begin{array}{r}1.00 \\
0.62 \\
0.62 \\
0.24 \\
-0.04 \\
0.06 \\
-0.30 \\
0.24\end{array}$ & $\begin{array}{r}1.00 \\
0.55 \\
0.17 \\
-0.03 \\
0.00 \\
-0.20 \\
0.15\end{array}$ & $\begin{array}{r}1.00 \\
0.21 \\
0.01 \\
0.09 \\
-0.25 \\
0.20\end{array}$ & $\begin{array}{r}1.00 \\
0.23 \\
0.26 \\
-0.44 \\
0.41\end{array}$ & $\begin{array}{r}1.00 \\
0.20 \\
-0.28 \\
0.27\end{array}$ & $\begin{array}{r}1.00 \\
-0.33 \\
0.35\end{array}$ & $\begin{array}{r}1.00 \\
-0.54\end{array}$ & 1.00 & & & & & & & & & & & & \\
\hline 9 素< & 0.16 & 0.08 & 0.14 & 0.27 & 0.15 & 0.25 & -0.32 & 0.36 & 1.00 & & & & & & & & & & & \\
\hline 10 走 & 0.17 & 0.09 & 0.16 & 0.30 & 0.16 & 0.21 & -0.34 & 0.33 & 0.48 & 1.00 & & & & & & & & & & \\
\hline 11 謴を跳ひ成えるる & 0.22 & 0.16 & 0.20 & 0.32 & 0.16 & 0.25 & -0.37 & 0.31 & 0.42 & 0.42 & 1.00 & & & & & & & & & \\
\hline & 0.17 & 0.06 & 0.16 & 0.29 & 0.17 & 0.29 & -0.37 & 0.34 & 0.48 & 0.45 & 0.45 & 1.00 & & & & & & & & \\
\hline 13 起立 & 0.11 & -0.01 & 0.09 & 0.26 & 0.15 & 0.25 & -0.30 & 0.28 & 0.36 & 0.35 & 0.38 & 0.51 & 1.00 & & & & & & & \\
\hline 14 闌眼片足立ち & 0.09 & 0.05 & 0.11 & 0.20 & 0.16 & 0.36 & -0.25 & 0.23 & 0.31 & 0.33 & 0.33 & 0.38 & 0.30 & 1.00 & & & & & & \\
\hline 15 震り物内立位保持 & 0.17 & 0.09 & 0.14 & 0.26 & 0.13 & 0.23 & -0.28 & 0.25 & 0.36 & 0.33 & 0.35 & 0.45 & 0.39 & 0.32 & 1.00 & & & & & \\
\hline 16 スボン & 0.08 & 0.05 & 0.09 & 0.23 & 0.19 & 0.24 & -0.29 & 0.24 & 0.32 & 0.26 & 0.35 & 0.42 & 0.41 & 0.27 & 0.35 & 1.00 & & & & \\
\hline 17 シャツ & 0.07 & 0.05 & 0.10 & 0.22 & 0.17 & 0.23 & -0.26 & 0.24 & 0.34 & 0.30 & 0.33 & 0.41 & 0.35 & 0.30 & 0.36 & 0.40 & 1.00 & & & \\
\hline 18 布団上げ下ろし & 0.14 & 0.13 & 0.12 & 0.22 & 0.17 & 0.20 & -0.28 & 0.26 & 0.36 & 0.30 & 0.38 & 0.41 & 0.36 & 0.26 & 0.36 & 0.44 & 0.40 & 1.00 & & \\
\hline & 0.30 & 0.23 & 0.25 & 0.29 & 0.14 & 0.23 & -0.34 & 0.30 & 0.38 & 0.33 & 0.47 & 0.40 & 0.33 & 0.30 & 0.35 & 0.36 & 0.34 & 0.45 & 1.00 & \\
\hline 20 上体起こし & 0.24 & 0.11 & 0.18 & 0.33 & 0.13 & 0.16 & -0.27 & 0.27 & 0.28 & 0.35 & 0.30 & 0.35 & 0.33 & 0.30 & 0.29 & 0.24 & 0.26 & 0.25 & 0.32 & 1.00 \\
\hline & -0.09 & -0.15 & -0.12 & -0.18 & -0.14 & -0.28 & 0.23 & -0.26 & -0.15 & -0.15 & -0.16 & -0.23 & -0.16 & -0.16 & -0.15 & -0.16 & -0.17 & -0.16 & -0.15 & -0.11 \\
\hline
\end{tabular}

注）網掛けの項目のみ有意性 $(\mathrm{p}<0.05)$ なし. 
表 5. ADL 得点と外的要因との関係

\begin{tabular}{|c|c|c|c|}
\hline & 健庵度"1 & 体力 & 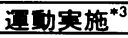 \\
\hline 1 直長 & $1,2>3$ & $1>2>3$ & $1,3,2>4$ \\
\hline 2 体重 & $1,2>3$ & $1,2>3$ & $3,2,1>4$ \\
\hline 3 握力 & $1>2>3$ & $1>2>3$ & $1>2,3>4$ \\
\hline 4 上体起こし & $1>2>3$ & $1>2>3$ & $1>2>3>4$ \\
\hline 5 長座体前埋 & $1>2>3$ & $1>2>3$ & $1,2>3>4$ \\
\hline 6 開眼片足立ち & $1>2>3$ & $1>2>3$ & $2>1>3>4$ \\
\hline 7 10m障要歩行 & $3>2>1$ & $3>2>1$ & $4>3>2,1$ \\
\hline 86 分间步行 & $1>2>3$ & $1>2>3$ & $1>2>3>4$ \\
\hline 9 歩く & $1>2>3$ & $1>2>3$ & $1>2>3>4$ \\
\hline 10 走る & $1>2>3$ & $1>2>3$ & $1>2>3>4$ \\
\hline 11 洋を跳び越える & $1>2>3$ & $1>2>3$ & $1>2>3>4$ \\
\hline 12 階段歩行 & $1>2>3$ & $1>2>3$ & $1>2>3>4$ \\
\hline 13 起立 & $1>2>3$ & $1>2>3$ & $1,2>3>4$ \\
\hline 14 開眼片足立ち & $1>2>3$ & $1>2>3$ & $1,2>3>4$ \\
\hline 15 乗り物内立位保持 & $1>2>3$ & $1>2>3$ & $1>2>3>4$ \\
\hline 16 ズボン & $1>2>3$ & $1>2>3$ & $1>2>3>4$ \\
\hline 17 シャツ & $1>2>3$ & $1>2>3$ & $1>2>3>4$ \\
\hline 18 布団上げ下ろし & $1>2>3$ & $1>2>3$ & $1>2>3>4$ \\
\hline 19 運搬 & $1>2>3$ & $1>2>3$ & $1>2>3>4$ \\
\hline 20 上体起こし & $1>2>3$ & $1>2>3$ & $1>2>3>4$ \\
\hline
\end{tabular}

注）表中は多重比較検定の結果を示す $(\mathrm{p}<0.05)$.

${ }^{* 1}$ 健康度自己評価：1. 大いに健康，2. 2. 3.あまり健康ではない

*2 体力自己評価：1．自信がある，2．普通である， 3. 不安がある

*3運動実施状況：1．ほとんど毎日，2．ときどき， 3.ときたま，4.しない

ADL 項目で, 健康度および体力自己評価が高い 者ほど ADL 得点も高い傾向が認められた。同様 に, 運動実施頻度が多い者ほど ADL 得点も高い 傾向を示した。

\section{5. 得点分布及び評価基準}

ADL 総合得点の得点分布および累積相対度数 分布を図 1 に示した．本研究の被験者5715名のう
ち, ADL 総合得点が 12 点であった者は 5 名 (0.1\%)のみであった. 13点から23点の範囲には 702 名 (13.5\%) が該当し, その平均得点は $20.5 \pm$ 2.46 点，24点以上には4495名 (86.4\%)が該当し， その平均得点は $30.2 \pm 3.45$ 点であった. それぞれ の ADL 得点分布の該当者における体力実測値を 比較した結果, ADL 得点が高い群ほどいずれの

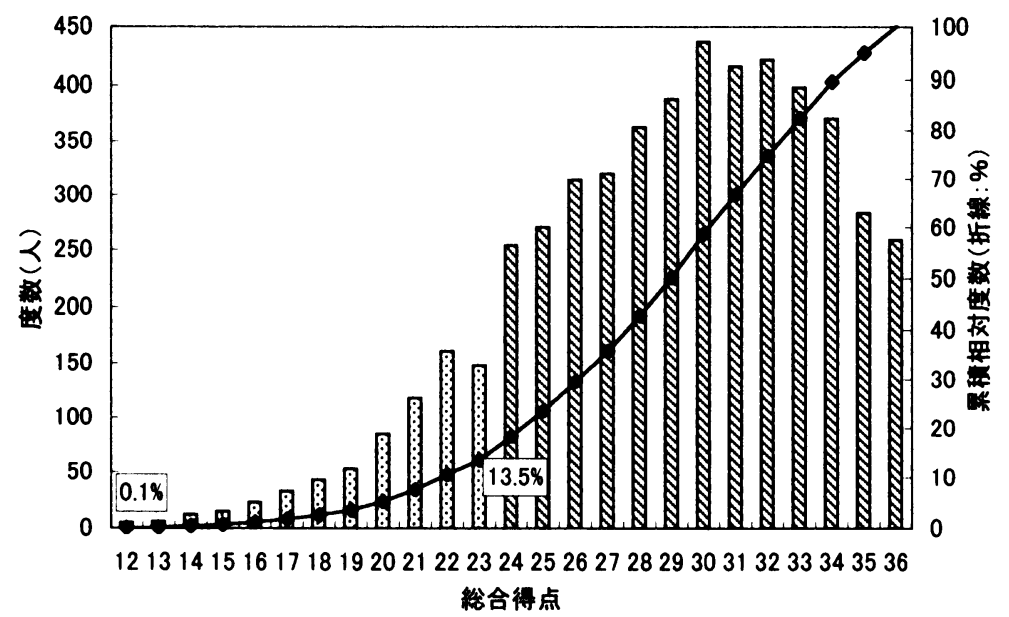

図 1. 総合得点分布 (度数 - 累積相対度数) 
体力実測值も有意に高い値を示した.

本研究では，スクリーニング項目として，成就 率から難易度が中程度およびやや低い下肢動作と して項目 1 (歩く), 項目 5 (起立), 項目 6 (開眼 片足立ち)の 3 項目, やや難易度が高い動作とし て項目 3 (溝を跳び越える)および項目 4 (階段歩 行)の 2 項目, 難易度が高い下肢動作として項目 2 (走る)および項目 11 (運搬)の 2 項目を取り上げ た. 項目 1 (歩く)， 5 (起立)， 6(開眼片足立ち) の 3 項目の回答がカテゴリ (1)(難易度が最も低い カテゴリ)であった者は29名のみであり，その総 合得点の平均は $15.5 \pm 2.90$ 点(得点範囲：12 22 点)であった(図 2 参照). 前述の 3 項目の回答が (1)以外であり, 且つ項目 3 および 4 のいずれかで カテゴリ (1)と回答した者は261名でその平均得点

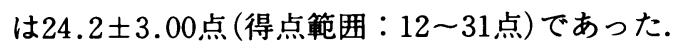

項目 2 および11においてカテゴリ(3)と回答した者 は933名で, その平均得点は $33.8 \pm 2.29$ 点(得点範

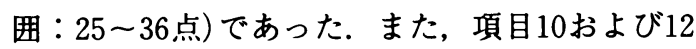
の回答がカテゴリ (1)であった者は57名で, その平 均得点は $18.5 \pm 4.60$ 点(得点範囲 : 12 28点)で
あった。

\section{考察}

1. ADL 項目の信頼性, 妥当性および種々の要 因との関連

本研究では, 我々の先行研究において在宅高齢 者の ADL 能力を評価するうえで有効と考えられ る ADL 12 項目の信頼性, および加齢, 体力実測 值, 健康度 - 体力自己評価, 運動実施状況との関 係を検討し，その有効性を検証することを目的と している.

信頼性に関して，再テスト法による評価の一致 度を検討した結果, 各項目について0.674〜0.886, 総合評価について0.943の相関係数が認められた。 これらの値は, 西嶋ほか ${ }^{3)}$ や古谷野ほか ${ }^{9)}$ などの 先行研究で報告されている值と同程度である. 全 ての項目に中程度以上の相関係数が認められたこ とに加え，2回のテストでの評定值の差が 2 で あった ( 1 回目で(1)に回答し, 2 回目で(3)に回答 した場合,またはその逆)者は認められず, 2 回 の評価の一致度は高いと考えられる.

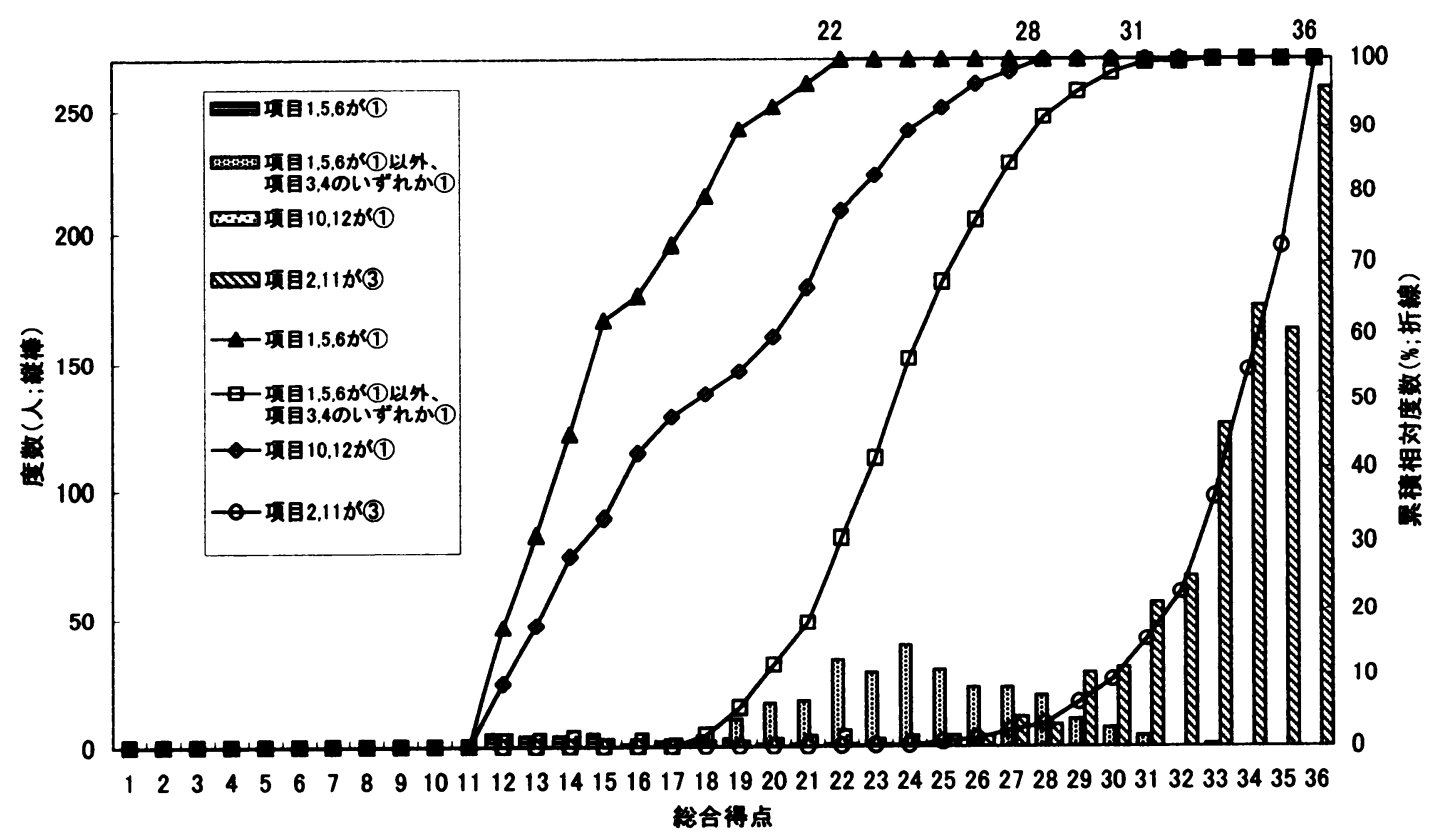

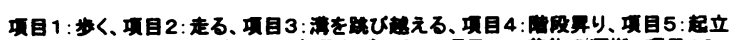

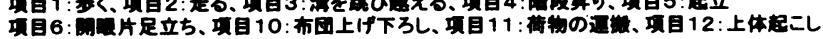

図 2. 粉合得点別得点分布 (度数 - 累積相対度数分布) 
先行研究において, ADL 能力と加齢 ${ }^{1,9 \sim 11)}$, 体力実測值 ${ }^{3,13}$ 17), 健康度 - 体力自己評価 ${ }^{5}$, 7,18) , 運動実施状況 ${ }^{19)}$ との関係が検討されてお り, ADL 能力が加齢に伴って低下することや, 実際の体力水準や健康・体力に関する自己評価, 活動性が高い者ほど ADL 能力に優れることが報 告されている. 本研究においても, 全ての ADL 項目と年齢, 体力実測值との間に有意な相関係数 が認められ，同様な傾向が確認された。また，本 研究において全ての ADL 項目が全ての体力テス ト項目と有意な関係にあったことは, ADL が, 特定の体力要素の関与を仮定した体力テスト項目 により測定される能力とは異なり1)，その成就に 種々の体力要素が複合的に関与することを示唆し ている. 年齢との相関係数は $-0.11 \sim-0.23$ 程度 であったが, 本研究では ADL 調査票と合わせて 文部省の新体力テストを実施したため, 被験者の 年齡幅が比較的狭い範囲 (65歳以上80歳未満)で あったことが影響していると考えられる。

自己の健康および体力に関する評価が高い者ほ ど実際の ADL 能力も高い傾向が認められた。健 常な在宅高齢者の場合, 健康度自己評価に関して 「あまり健康ではない」, あるいは体力自己評価に 関して「不安がある」と回答した者の ADL 得点 の平均値は，「走る」と「上体起こし」を除き 2 点以上であり, 健康・体力に関する自己評価が低 い者でも，ある程度の者がほとんどの ADL につ いて，何らかの支助(つかまり)がある，または， 難易度があまり高くない動作であれば成就できる 傾向にあった。しかし，自己評価の低い者は高い 者と比較して, $\mathrm{ADL}$ 得点に加え, 体力実測値も 有意に低いことから，自己評価が低い者に対して は，体力テストの実施に関して十分注意する必要 があるであろう。運動実施に関しても，実施頻度 が高い者の ADL 得点が有意に高い傾向が認めら れた. 南ほか ${ }^{19)}$ は, 特に筋力が関与する ADL の 成就能力と運動習慣に有意な関係が認められたこ とを報告している. 本研究では, 動作領域や身体 使用部位に関わらず，全ての ADL 項目と運動実 施との間に有意な関係が認められている.このこ とは, 高齢者の場合, ADL 成就能力を維持する
という点では，適度な運動を実施する習慣を有し ていることが重要と考えられる.

以上より, 本 ADL 調査票および各項目の信頼 性および妥当性は高く, 在宅高㱓者の ADL 能力 を評価する指標として有効と考えられる。

\section{2. 本指標の得点分布および評価基準}

本 ADL 調査票は，第一に高齢者が自立した日 常生活を営むのに必要な動作能力を有しているか の評価，第二に体力テストを安全に実施するため のスクリーニングテストとしての利用を意図して いる. したがって, 日常生活に必要な動作能力を 有し，体力テストの実施が可能と判断するための 基準や，体力テストの実施に関して危険性が高い と判断するための基準を，総合得点や個々の ADL 項目の反応特性を用いて示す必要があろう.

総合得点における全被験者の平均值は $28.9 \pm$ 4.7点, 最頻値も28点である. 5000 名を越える標 本を用いたことで正規分布に近い得点分布を示し たが，全体的に得点分布が右側 (高得点域)に偏る 傾向にある．これは，体力テストを実施可能な一 定水準以上の体力水準を有する者であれば，本調 査票のほとんどの項目で満点を取ることができた ためと考えられる．本調査票は，第一に日常生活 の自立や体力テストを安全に実施するために必要 な一定水準以上の身体能力の有無を確認するため のテストである. したがって, 本調査の ADL 得 点が, 極めて体力水準が高い高齢者の動作能力の 個人差を十分に反映する必要性はさほど高くな く, 体力テストの実施の可否を判断するうえで特 に問題ないと考えられる.

総合得点の12点および24点を基準とし，12点以 下，13点～23点，24点以上における総合得点分布 をみると，12点であった者は, 本研究で対象とし

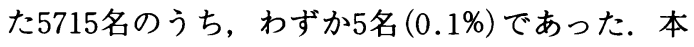
$\mathrm{ADL}$ 調查票の 12 項目のうち 3 項目 (「歩く：5 10分程度」「階段歩行：手すりや壁につかまらな いと昇れない」「シャツのボタンをとめる：両手 でゆっくりとならできる」)以外の項目は, カテゴ リ(1)の内容が「成就できない」である. 本調査票 の総合得点が12点以下 (全てカテゴリ (1)に回答. 
何らかの理由により回答が困難な項目がある)を 示す者は, 健常な在宅高齢者の中で希であること, そして, 日常生活の中で行われる多くの動作の成 就が困難であり, 体力テストの実施が極めて困難 と考えられる. 絵合得点が12点〜23点の者（主に カテゴリ(2)および(3)に回答)は702名(13.5\%)，24 点以上の者(主にカテゴリ (2)および(3)に回答)は 4495名 (86.4\%)であった。 これらの高齢者におけ る体力実測値の平均値を男女別に文部省の基準に 当てはめ, 10段階評価で示してみると，23点以下 の者の場合, 男女とも開眼片足立ち(評定値 $=6$ ) を除く全ての項目で評定値が 4 以下であった. 一 方, 24 点以上の者は, 男女とも評定値が全て 5 以 上(開眼片足立ちは 8)であり, 体力水準が平均的 かそれよりも高い傾向にある。このことから， $\mathrm{ADL}$ 調査票において23点以下であることは, 体 力水準が平均以下で, 日常生活における動作の成 就にもやや不安があることを意味し, 体力テスト の実施に危険性を伴う可能性が高いことから，実 施可能な体力テスト項目について慎重な検討が必 要と考えられる．また，24点以上であることは， 日常生活動作の成就には特に問題はなく, 体力水 準も平均的水準以上であることを意味している. 個々人の状態に応じてテストの実施を慎重に検討 する場合もあるが, 一般的には, 全ての体力テス トについてほほ安全に実施できると考えられる. 以上のことから, ADL 総合得点の 12 点以下, 23 点以下，24点以上を用いた体力テスト実施に関す るスクリーニング基準が提示できると考えられ る.

また，項目による体力テストのスクリーニング も試みた，高齢者において，移動能力や下肢に関 する動作能力の低下は生活範囲を狭め, 結果的に 種々の身体能力が低下することが指摘されており 20,21), 下肢の機能水準を評価することの意義は 高い. そこで本研究では, スクリーニング項目と して, 成就率から難易度が中程度およびやや低い 下肢動作として項目 1 (歩く), 項目 5 (起立), 項 目 6 (開眼片足立ち)の 3 項目, やや難易度が高い 動作として項目 3 (溝を跳び越える) および項目 4 (階段歩行)の 2 項目, 難易度が高い下肢動作とし
て項目 2 (走る)および項目11 (運搬)の 2 項目を取 り上げた. そして, 各項目の回答が, 項目 1,5 , 6 においてカテゴリ11)の場合(基準 1), 項目 1 , 5,6 においてカテゴリ(1)以外でかつ項目 3，4 においてカテゴリ(1)であった場合(基準 2), さら に，項目 2，11においてカテゴリ(3)であった場合 (基準 3 )をそれぞれスクリーニング基準として得 点傾向を分析した.これらの基準に用いた項目は 下肢動作であることから，体力テストを実施する 際における立位姿勢の安定性や移動時の安全性な どに関する危険性を予測できると考えられる。

これら 3 つの基準における $\mathrm{ADL}$ 得点の平均は それぞれ, 15.5点, 24.2点, 33.8点であり, これ らの項目の反応から, ADL 能力水準の低い群, 中程度の群, 高い群への分類が可能と考えられる. また，各基準に該当した者の体力テストにおける 評定值は, 基準 1 において $2 \sim 5$, 基準 2 で 3 8, 基準 3 で $6 \sim 9$ であり, 体力水準の違いも反 映している. 基準 1 に該当した場合には，下肢の 機能が劣っていることが予想され, $10 \mathrm{~m}$ 障害物 歩行や 6 分間歩行, 開眼片足立ちなどの体力テス 卜項目の実施を勧められない，基準 2 に該当する 場合にも,これらの体力テスト項目の実施は十分 慎重に検討すべきであると考えられる．基準 3 に 該当した場合には，下肢の機能はかなり高い水準 にあることが予想され，特別な場合を除いてはほ ほ安全に体力テストが実施できると考えられる.

加えて, 60 歳以上の高齢者の 50 70\%が抱える と言われる腰痛の問題 ${ }^{22)}$ を考慮し, 腰痛がある 場合に成就が困難と考えられる項目として項目 10 (布団の上げ下ろし)および項目 12 (上体起こし)を 取り上げた．本研究の被験者の場合でも，体力テ スト 6 項目中, 上体起こしの不実施率は最も高く, 腰に問題や不安を抱えている高齢者が多いこと や，上体起こしテストに関する事前のスクリーニ ングの重要性が示唆される.これら項目10および 12の回答が11であった者の ADL 得点は18.5点と 低く, 上体起こしテスト以外の体力テストの実施 に関しても慎重な検討が必要と考えられる. 


\section{ま と め}

本研究では, 第一に, ADL 12 項目について, 信頼性, 実証的妥当性, および外的要因との関係 について検討すること，第二に，得点分布などを 分析し，体力テスト実施に関するスクリーニング 基準を検討することを目的とした。分析の結果, ADL 項目の信頼性は高く, 年齢や体力実測值と も有意な関係を示した．また，健康や体力に関す る自己評価や運動実施状況とも有意な関係にあ り, 本研究で用いた ADL 項目の有効性が示唆さ れた。ささらに, 標本の得点分布および体力テスト 得点の評価値を分析した結果, 体力テストを実施 する際のスクリーニング基準として ADL 調査票 の総合得点を用いた評価 (12点以下, 12点〜23点, 24 点以上)および項目を用いた評価(項目 $1 ， 5$, 6 の回答が(1)の場合, 項目 $1,5,6$ の回答が(1) 以外で項目 3,4 が(1)の場合, 項目 2,11 (3)の 場合，項目10，12が(1)場合)がそれぞれ有効と考 えられた。

本研究は, 平成 $10 \cdot 11$ 年度文部省科学研究費補助金 (基盤研究 C (2) 課題番号10680020および基盤研究 B (1) 課題番号09400015)により実施された.

（受理日 平成12年 2 月19日）

\section{文献}

1）出村慎一・松沢甚三郎 - 野田洋平 - 南雅樹 - 郷司 文男・佐藤進・小林秀紹・西嶋尚彦 (1999) 在宅高 齢者の日常生活動作の特徴, 体育学研究 44-2 : 112-127.

2）田中喜代次・李 美淑 (1995) 高齢社会における健 康 - 体力評価の意義, 筑波大学体育科学系紀要 $18: 27-36$.

3）西嶋洋子・荒尾 孝・種田行男 - 永松俊哉・青木 和江・江橋 博 - 一木昭男 (1993) 広範囲の高齢者 に利用可能な体力評価のための調査法の開発に関 する研究一体力自己評価 (身体活動能力評価)の妥 当性の検討一, 体力研究 82:14-28.

4）新井 忠 (1998) 高齢者の体力テスト(文部省), 臨 床スポーツ医学, 15-8:849-857.

5）出村慎一・佐藤 進・南 雅樹 - 野田洋平 - 松沢 甚三郎・宮口尚義・西䳋尚彦・郷司文男・多田信 彦・新井 忠 (1999) 在宅高齡者の各種日常生活動 作 $(\mathrm{ADL}) に お け る$ 相互の関連性と難易度の検討, 教育医学 44-3: 500-511.
6）出村慎一・佐藤 進・松沢甚三郎・野田洋平 - 宮 口尚義・多田信彦・小林秀紹 - 郷司文男 - 南 雅 樹 (2000) 在宅高齢者の日常生活動作能力評価に有 効な ADL項目の検討一加龄, 体力テスト, 項目相 互間の関係から一, 体力科学 49-2: 237-246

7）佐藤 進・出村慎一・松沢甚三郎・小林秀紹・豊 島慶男 (1999) 要介助高齡者の日常生活動作能力の 検討一加龄, 自覚的健康感 - 体力感, 疾病との関 係から一, 体育学研究 44-1:13-24.

8）佐藤 進 - 出村慎一・松沢甚三郎 - 野田洋平 - 宮 口尚義・多田信彦・小林秀紹・郷司文男・南 雅 樹 (2000) 在宅高龄者のための ADL 調査票の作成一 有効な調查項目および評価尺度の提案, 体育学研 究 45-4 (印刷中).

9）古谷野 亘・柴田 博 - 中里克治 - 芳賀 博 - 須 山靖男 (1987) 地域老人における活動能力の測定一 老研式活動能力指標の開発一, 日本公衆衛生雑誌 $34: 109-114$.

10）出村慎一・佐藤 進 - 小林秀紹 - 春日晃章 - 豊島 義男 (1999) 要介助高齢者の日常生活動作能力評価 票の作成, 日本公衆衛生雑誌 $46: 25-34$.

11）生山 匡・後藤芳雄・西嶋洋子・喜多尚武・江橋 博 (1991) 広範囲の高龄者に利用可能な身体活動水 準調査法の開発, 体力研究 $78: 25-46$.

12) Lawton, M. P. and Brody, E. M. (1969) Assessment of older people : Self-maintaining and instrumental activities of daily living. Gerontologist $9: 179-186$.

13）金禧植 - 松浦義行 ·田中喜代次 - 稲垣 敦 （1993）高齢者の日常生活における活動能力の因子 構造を評価のための組テスト作成, 体育学研究 $38:$ 187-200.

14）木村みさか ・平川和文・奥野直 - 小田慶喜 - 森本 武利・木谷輝夫 ·藤田大祐 - 長田久紀 (1989) 体力 診断バッテリーテストからみた高齡者の体力測定 值の分布および年齢との関連, 体力科学 $38: 175-$ 185.

15) Kempen, G. I. J. M. and Suurmeijer, J. P. B. M. (1990) The development of a hierarchical polychotomous ADL-IADL scale for noninstitutionalized elders. Gerontologist $30:$ 497-502.

16) Suthichai, J., Pirom, K. and Shah, E. (1994) The meaning of activities of daily living in a Thai elderly population: Development of a new index. Age and Ageing 23, 97-101.

17) Reuben, D. B., Laliberte, L., Hiris, J. and Mor, V. (1990) A hierarchical exercise scale to measure function at the advanced activities of daily living (AADL) level. AGS 38 : 855-861.

18）細川 徹 - 坪野吉孝 - 辻 一郎 - 前沢政次 - 中村 隆一(1994) 拡大 ADL 尺度による機能的状態の評価 1）地域高齢者, リハビリテーション医学 31-6: 399-408.

19）南 雅樹 - 出村慎一・春日晃章 - 郷司文男 (1997) 在宅高龄者における日常生活動作と諸要因との関 連一運動習慣, 外出状況, 体力, 健康, 日常生活 の不自由さについてー教育医学 42:170-181. 
20) Sato, S., Demura, S., Kobayashi, H., Goshi, F., Minami, M., Nagazawa, Y. and Yamaji, S. (1999) Characteristics of ADL ability on partially dependent older adults : Comparison among different ambulatory activities levels. Applied Human Science 18-5: 169-174.

21) Winograd, C. H., Lemsky, C. M., Nevitt, M. C., Nord- strom, T. M., Stewart, A. L., Miller, C. J. and Bloch, D. A. (1994) Development of a physical performance and mobility examination. J. A. G. S. 42 : 743-749.

22）藤原勝夫・碓井外幸・立野勝彦 (1996) 身体機能の 老化と運動訓練ーリハビリテーションから健康增 進までー, 日本出版サービス, 東京, p 111-161. 